M. Wiese,

C.H. van Heerden,

Y. Jordaan

\title{
THE ROLE OF DEMOGRAPHICS IN STUDENTS' SELECTION OF HIGHER EDUCATION INSTITUTIONS
}

\author{
M Wiese: Department of Marketing and Communication Management, University of Pretoria. \\ C H van Heerden: Department of Marketing and Communication Management, University of Pretoria. \\ $Y$ Jordaan: Department of Marketing and Communication Management, University of Pretoria.
}

\section{SYNOPSIS}

Purpose: To investigate the choice factors students consider when selecting a higher education institution, with a focus on the differences between gender and language groups.

Problem investigated: The educational landscape has seen several changes, such as stronger competition between institutions for both student enrolments and government funding. These market challenges have led to an interest in students' institution selection processes as it has implications for the way higher education institutions (HEls) manage their marketing and recruitment strategies. The research objective of this study was to identify the most important choice factors of prospective South African students. It also aimed to determine if any gender and language differences exist with regard to students' institution selection processes.

Methodology: A convenience sample of 1241 respondents was drawn, representing six South African universities. A selfadministrated questionnaire was used to collect the data. Questions from the ASQ (Admitted Student Questionnaire) and CIRP (The Cooperative Institutional Research Programme) were used and adapted to the South African context after pilot testing. Hypotheses were analysed using the multivariate analysis of variance (MANOVA) test with Wilks' lambda as the test statistic.

Findings/Implications: Irrespective of gender or language, the most important choice factor for respondents was the quality of teaching at HEls. The findings showed that males and females differ according to the selection of certain choice factors which suggest that HEls can consider recruitment strategies for each gender group. Significant differences between the language groups were found for 17 of the 23 choice factors, signalling that different language groups make decisions based on different choice factors. African language-speaking students have, amongst other, indicated that the multiculturalism of the institution is a very important choice factor for them.

Conclusion: The findings provide HEls with an indication of the importance of choice factors considered by students in selecting a $\mathrm{HEI}$. This will enable HEls to use their limited funds more efficiently to attract the right calibre student (recruitment policies), to create a unique position, to segment the student market more appropriately and to gain a competitive advantage.

Keywords: choice factors; institution selection; student decision-making; higher education marketing; demographics, recruitment

\section{INTRODUCTION}

Globally, as well as in South Africa, the non-profit sector and higher education are undergoing a period of change. Higher education institutions (HEls) do not exist in isolation, especially since the environment in which higher education institutions operate seems to be unstable and turbulent. HEls as non-profit organisations will only develop and grow if they have knowledge of their environment and have the ability to adjust to the economic and social changes.

The process of transformation of higher education in South Africa expects institutions to deliver the much needed graduates for social and economic development, while simultaneously addressing equity and diversity. One way to achieve this is to better understand the student market in terms of the choice factors they consider when deciding on enrolling with a higher education institution. 
M. Wiese, C.H. van Heerden, Y. Jordaan
The role of demographics in students' selection of higher education institutions

The purpose of this paper is to investigate the choice factors students consider when selecting a higher education institution, with a focus on the differences between gender and language groups. First, the paper briefly addresses the changing landscape of higher education, after which it provides a theoretical overview of a typical decision-making process during institution selection. Next, the research objectives and methodology are described, and the research results reported. This is followed by a discussion of the implications of the findings, as well as a brief conclusion highlighting the limitations of the study with suggestions for further research.

\section{THE CHANGING LANCSCAPE OF HIGHER EDUCATION}

Various authors have noted the pressures and changes in the higher education landscape (Whyte, 2001; Espinoza, Bradshaw \& Hausman, 2002; Rindfleish, 2003; Van Louw \& Beets, 2008). The "post-apartheid" period (after 1994) marked the start of major restructuring of the higher education landscape in South Africa. Locally, higher education institutions (HEls) are faced with issues of globalisation, broadening access to higher education, changes in language policies, changes in government funding, an increased emphasis on technology, transformation policies, mergers, changing student profiles and increased competition (Jansen, 2003; Van Niekerk, 2004; Akoojee \& Nkomo, 2007; De Vries, 2007).

Currently in South Africa, nearly one in five school-leavers who pass Grade 12 enters a higher education institution, with over 700000 students studying at 23 different higher education institutions across South Africa (Higher Education South Africa, 2008). With this changing landscape, HEls will have to become more market-oriented as they increasingly compete for students and funding. The increase in competition in the $\mathrm{HEI}$ market can be attributed to several factors. The first is the opening of universities to all races provided they meet the access criteria (Akoojee \& Nkomo, 2007). The second is pressure on HEls to transform their student profiles to become more representative of the broader population (Ministry of Education, 2002). The third is a limited pool of matriculants, particularly African learners, who meet the entrance requirements to attend a university. The final factor is changes in the funding formula for HEls which has placed greater emphasis on throughput (Wangenge-Ouma \& Cloete, 2008). This has accentuated the imperative for institutions to recruit high-achieving students who are likely to graduate in minimum time (Smit \& Schonefield, 2000). The noted increase in competition for funding is also compelling HEls to make their programmes more relevant for the South African market and to consider eliminating activities that are not commercially profitable, even if it may have academic value. Furthermore, increased pressure from government on broader access implies that institutions must ensure that they recruit and attract students from different ethnic orientations and gender groups.

These marketing challenges have sparked interest in institutions' student recruitment processes. Understanding the decision-making processes of students in terms of how they select a HEl will assist institutions to target the student market better. Student recruitment has therefore become increasingly important and numerous studies have examined institutions' recruitment processes in an attempt to identify factors influencing students' choices (Chapman, 1981; Litten, 1982; Kealy \& Rockel, 1987; Espinoza et al, 2002; Hoyt \& Brown, 2003; Gray \& Daugherty, 2004; Punnarach, 2004). An institution that has knowledge about the factors that influence students' application and enrolment decisions can increase the fit between the student and the institution. Institutions can use student selection process information to develop marketing strategies designed to attract sufficient numbers of students with the desired academic, as well as non-academic, characteristics such as gender and ethnic orientation.

\section{THE DECISION-MAKING PROCESS FOR HIGHER EDUCATION SELECTION}

The Engel, Blackwell and Miniard model outlines consumer behaviour as a process consisting of two parts: the process, which consists of fives steps, and the internal and external factors which influence the process (Berman \& Evans, 2001; Hawkins, Best \& Coney, 2004). The decision-making process which students follow 
M. Wiese, C.H. van Heerden, Y. Jordaan
The role of demographics in students' selection of higher education institutions

when selecting a $\mathrm{HEl}$ is generally a lengthy process because individuals usually progress through all five steps, namely problem/need recognition, information search, evaluation of alternatives, selection, as well as the post-purchase evaluation processes. The steps in the decision-making process can be used by HEls to identify areas in which they can influence students' behaviour.

The first step in the decision-making process, problem/need recognition, occurs when prospective students recognise a need to further their education. The emphasis of the second step is the provision of information. The sources of information that students consult, the type of information they need and the amount of search students engage in, are important information for institutions to obtain as it will enable them to use the media more effectively to reach students. The third step in the decision-making process, namely the evaluation of alternatives (in this case various HEIs), is the focus of this study and identifies important evaluation/selection criteria (also referred to as choice factors). If institutions know which factors students use to evaluate and choose an institution, and the relative importance of each, they can ensure that their image, positioning and marketing strategies implicitly contain the gist of the evaluation criteria. The fourth step involves the selection of the institution and the purchase of a service product (in this case education), by paying the registration fees and enrolling at the institution. The fifth step consists of the post-purchase processes, namely dissonance (doubt or anxiety), service product use and evaluation. The last step in the decision-making process entails that students now use the education product which can have a negative (fail) or positive (pass) outcome.

Knowledge of the decision-making processes of students can provide HEls with insight into their market and the development of a differentiated marketing strategy. Furthermore, an understanding of the relative importance of choice factors as a decision in students' selection processes, can add to the refinement of targeted marketing strategies.

\section{Evaluation criteria as part of the decision-making process}

The importance assigned to evaluative criteria can differ from student to student and knowledge of these differences can assist HEls to develop and manage their marketing mix in such a way as to ensure successful recruitment (Hawkins et al, 2004).

A review of previous international studies (mainly reports from English-language literature and conducted in the USA) revealed a variety of potential choice factors considered by students when selecting a HEI. Van Dimitrios (1980) identified media, institutional accessibility, academic programmes and non-academic programmes as the main choice factors. Bajsh and Hoyt (2001), and Bradshaw, Espinoza and Hausman (2001) identified five main factors considered by students when selecting a HEI. These include quality and responsiveness of staff, research activities, social opportunities, economic considerations and the size of the institution. Espinoza et al (2002) identified campus safety and flexibility in course offering times as additional factors to those identified in previous literature. Arpan, Raney and Zivnuska (2003) identified three main factors: academic rating; athletic rating; and news coverage. Punnarach (2004) added the famousness of the university, public relations and stability as additional choice factors.

Drew and Michael's (2006) Canadian study determined that students value location, non-academic services and scholarships when selecting a $\mathrm{HEl}$. A research study carried out under Chinese students revealed that they choose international HEls based on affordability, prestige and quality (Hannukainen, 2008). Findings from an Australian study identified reputation and prestige as important factors, but added that first-year students at the University of South Australia also ranked career preparation, specific academic programmes, distance from home, quality of research programmes and library resources as having a strong influence on their choice of university (Martin, 1994).

One South African study identified operational activities, auxiliary services, reputation of the institution and admission requirements as factors that influence students' expectations (De Jager \& Du Plooy, 2006). In another recent South African study, five subgroups of choice factors were identified, namely employment 
M. Wiese,

C.H. van Heerden,

Y. Jordaan

The role of demographics in students' selection of higher education

institutions

possibilities, course content, student experiences, sporting aspects and financial considerations (Bonnema \& Van der Waldt, 2008).

Many previous studies distinguish between the importance levels of different choice factors (Sevier, 1993; Geraghty, 1997; Davis, 1998; Freeman, 1999; Bers \& Galowich, 2002; Price, Matzdorf, Smith \& Aghai, 2003; Mills, 2004; Shin \& Milton, 2006). Previous research findings not only suggest a difference in the importance of choice factors, but also possible differences between groups of students, especially between males and females, as well as different language groups.

\section{Gender and home language differences in higher education selection}

According to Hoyer and Maclnnis (2001:384), gender roles are changing, and males and females differ in terms of consumer traits, information processing, decision-making styles and buying patterns. Gender influences both purchase and consumption situations, as physiological differences between male and female may lead to specialised service product needs (Sheth, Mittal \& Newmand, 1999; Arnould, Price \& Zinkhan, 2004). Research suggests a variety of gender differences with regard to the choice factors used to select a HEI (Galotti \& Mark, 1994; Desjardins, Dunbar \& Hendel, 1999). HEls need to be aware that differences exists which affect how HEls reach and influence each gender group with appropriate communication messages. Although Litten (1982) found that differences between genders are smaller than differences between ethnic groups, he reported that females rated residential life as a more important factor in the selection process than their male counterparts. Mansfield's research (2005) shows student gender differences in terms of the importance of financial aid, security, academics, atmosphere and religious culture. The most important criteria for female students proved to be academics and for male students it was tuition. Findings from a South African study indicated that female students view security as a more important choice factor than their male counterparts (De Jager \& Du Plooy, 2006).

Many authors note the importance of the role of language in post-apartheid South Africa (Foley, 2004; Divala \& Waghid, 2007; Hay, 2008). Much of the inequality and inaccessibility of HEls in the past originated from class distinctions and discrimination based on linguistic abilities (Brand, 2003). Language has been seen as a barrier to access and success in higher education, mainly because African and other languages have not been developed as academic languages and in so far the majority of students entering higher education are not fully proficient in English or Afrikaans (Ministry of Education, 2002). Most universities in Africa use English and French as media of instruction, with the exception of Afrikaans in South Africa and Arabic in Egypt. Many South African higher education institutions offer their courses in English, with some offering core programmes in another language (for example Afrikaans) as a commitment to the particular community (Van der Walt \& Brink, 2005). Worth noting is that it has been said that certain language groups have a unique style of thought which may affect the way they make choices (Kimmerle in Brand, 2003; Bechan \& Visser, 2005; Meier, 2007; Hay, 2008). This raises the question whether students from different home languages would use a different set of criteria when deciding on a HEI? It was therefore postulated that differences may be expected between different home language groups (more specifically Afrikaans, English and African language groups).

\section{RESEARCH OBJECTIVES AND HYPOTHESES}

The research objectives were to identify the top ten choice factors for each gender and language group. Furthermore, it was to determine whether there are differences between gender groups in terms of their importance rating for the different choice factors. The last objective was to establish whether there are differences between language groups and the importance rating of their choice factors when selecting a $\mathrm{HEI}$.

From the research objectives the following hypotheses were formulated:

$\mathrm{H}_{0}$ : Male and female students do not differ regarding the importance they attach to choice factors.

$\mathrm{H}_{1}$ : Male and female students differ regarding the importance they attach to choice factors. 
M. Wiese,

C.H. van Heerden, Y. Jordaan
The role of demographics in students' selection of higher education institutions

$\mathrm{H}_{0}$ : Students speaking different home languages do not differ regarding the importance they attach to choice factors.

$\mathrm{H}_{2}$ : Students speaking different home languages differ regarding the importance they attach to choice factors.

\section{RESEARCH METHODOLOGY}

Due to limited funding and a lack of the necessary permission from the Department of Education to include Grade 11 and 12 high school learners in the research, a decision was made to approach first-year Economic and Management Sciences students from public South African HEls. Six institutions agreed to participate in the study, namely the University of Pretoria, the Tshwane University of Technology, the University of Johannesburg, the University of the Free State, the University of KwaZulu-Natal, and the University of North West. The fieldwork was conducted among first-year students in the beginning of the year (February and March) to ensure that they could still recall what influenced their HEl selection process. Menon, Saiti \& Socratous (2007) suggested that first-year students are considered to be suitable substitutes for high school learners as they still have a relatively accurate recollection of the decision-making process which had preceded their entry into higher education.

A non-probability, convenience sample was used as the respondents were chosen on the basis of being available or accessible during normal lecture times. Identified lecturers at each institution acted as fieldworkers. No incentives for completing the questionnaires were provided to respondents and participation was voluntary and anonymous. A total of 250 questionnaires were distributed to each of the six HEls, thus a total of 1500 questionnaires. An overall response rate of 83 per cent was achieved as 1241 of the distributed questionnaires were completed.

A self-administrated questionnaire was used to collect the data. Questions from the ASQ (Admitted Student Questionnaire) and CIRP (The Cooperative Institutional Research Programme) were used and adapted to the South African context after pilot testing. The ASQ is used by institutions to determine admitted students' perceptions of their programmes, recruitment literature, financial aid packages, competition, the institution's image and characteristics (College Board, 2005). The CIRP programme assists stakeholders in higher education research to understand the interest, values, attitude and self-reported abilities of new first-year students (Higher Education Research Institute, 2004).

The questionnaire consisted of Sections $A$ and $B$ and was available in English and Afrikaans. (A copy of the questionnaire is available from the authors.) In Section A of the questionnaire, a five-point Likert scale was used to measure the identified choice factors and each scale item had five response categories ranging from not important at all (1) to extremely important (5). Section B of the questionnaire contained questions to measure the socio-demographical status of respondents, such as age, gender and home language.

The significance level for the hypothesis tests was set at 5 per cent $(\alpha=0.05)$. Both hypotheses were analysed using the multivariate analysis of variance (MANOVA) test which assesses the differences between groups collectively rather than individually using univariate tests. The Wilks' lambda was the test statistic used to assess the overall significance of the MANOVA. Because the multivariate test of MANOVA shows only an overall significant difference, univariate analyses and, where necessary, Scheffé post hoc tests were performed to reveal more specific differences between groups on each of the identified choice factors.

\section{RESEARCH RESULTS}

\section{Respondent profile}

Females represented 64 per cent of the sample, while 36 per cent of the respondents were male. The majority of the respondents (75 per cent) were younger than 20 years. South Africa has 11 official languages, and in this respondent group, Afrikaans, English and Zulu were the three most prominent home languages. The majority of respondents (39\%) indicated one of the nine African home language options, namely 
M. Wiese,

C.H. van Heerden, Y. Jordaan
The role of demographics in students' selection of higher education institutions

Northern Sotho (8\%), South Sotho (4\%), Ndebele (1\%), Tswana (4\%), Zulu (14\%), Venda (1\%), Tsonga (1\%), Swazi (3\%) and Xhosa (3\%). This was followed by 38 per cent Afrikaans- and 21 per cent Englishspeaking respondents. The remaining 2 per cent belonged to "other home languages" such as Portuguese and German.

\section{Gender group differences}

The first research objective was to identify the top ten choice factors for each gender group. Table 1 provides the top ten choice factors (based on mean values) according to the relative importance for each gender group.

Table 1: Top ten choice factors according to gender

\begin{tabular}{|l|l|l|l|l|}
\hline No & Male & $\begin{array}{l}\text { Mean } \\
\text { Value }\end{array}$ & Female & $\begin{array}{l}\text { Mean } \\
\text { value }\end{array}$ \\
\hline 1 & Quality of teaching & 4.46 & Quality of teaching & 4.57 \\
\hline 2 & Employment prospects & 4.36 & Campus safety and security & 4.50 \\
\hline 3 & Academic facilities & 4.19 & Employment prospects & 4.50 \\
\hline 4 & Campus safety and security & 4.11 & International links & 4.24 \\
\hline 5 & International links & 4.11 & Academic facilities & 4.24 \\
\hline 6 & Language policy & 4.03 & Language policy & 4.09 \\
\hline 7 & Image of the institution & 4.01 & Image of the institution & 4.08 \\
\hline 8 & Academic reputation & 4.00 & Flexible study mode & 4.06 \\
\hline 9 & Flexible study mode & 3.97 & Wide choice of subjects/courses & 4.03 \\
\hline 10 & Wide choice of subjects/courses & 3.88 & Academic reputation & 4.02 \\
\hline
\end{tabular}

From Table 1 it is evident that quality of teaching was the most important factor for both genders. There were also similarities in the last three factors on the list for both males and females, namely academic reputation, flexible study mode and wide choice of subjects. Although females attached a slightly higher importance to image of the institution and language polices (higher mean values) than male students, both factors were sixth and seventh on the two lists. Interesting to note is that the top five factors were the same for both groups, although they differed in the ranking and were in all instances more important to female students. Thus, although the ranking order of some of the factors differed, the top ten factors for both groups were the same.

In Hypothesis 1 it was envisaged to determine whether male and female students differed regarding the importance they attach to the 23 choice factors when selecting a HEI. Significant results are indicated in bold print in Table 2. The mean values of the two gender groups and the MANOVA result of the hypothesis test are also shown in Table 2.

Table 2: Mean values and MANOVA results for different gender groups

\begin{tabular}{|l|l|l|l|}
\hline CHOICE FACTORS & Male & Female & Univariate Analyses \\
\hline Wide choice of subjects/courses & 3.88 & 4.03 & $\mathbf{0 . 0 2 0 7}$ \\
\hline Quality of teaching & 4.46 & 4.57 & $\mathbf{0 . 0 2 0 9}$ \\
\hline Academic facilities & 4.19 & 4.24 & 0.4102 \\
\hline Entry requirements & 3.62 & 3.82 & $\mathbf{0 . 0 0 2 5}$ \\
\hline Fees & 3.59 & 3.76 & $\mathbf{0 . 0 2 6 4}$ \\
\hline Location of institution & 3.75 & 3.64 & 0.1465 \\
\hline Sport programmes & 2.86 & 2.65 & $\mathbf{0 . 0 0 9 2}$ \\
\hline Social life on campus & 3.34 & 3.17 & $\mathbf{0 . 0 4 2 8}$ \\
\hline Attractiveness of campus & 3.52 & 3.54 & 0.7612 \\
\hline
\end{tabular}


M. Wiese,

C.H. van Heerden, Y. Jordaan
The role of demographics in students' selection of higher education institutions

\begin{tabular}{|l|l|l|l|}
\hline Campus safety and security & 4.11 & 4.50 & $\mathbf{0 . 0 0 0 0}$ \\
\hline On-campus housing & 3.00 & 3.25 & $\mathbf{0 . 0 0 7 3}$ \\
\hline Parents attended the institution & 1.86 & 1.81 & 0.4448 \\
\hline Siblings attended the institution & 2.01 & 1.86 & $\mathbf{0 . 0 4 9 4}$ \\
\hline Friends attended the institution & 2.52 & 2.24 & $\mathbf{0 . 0 0 0 7}$ \\
\hline Academic reputation & 4.00 & 4.02 & 0.7024 \\
\hline Financial assistance & 3.63 & 3.77 & 0.1164 \\
\hline Language policy & 4.03 & 4.09 & 0.3947 \\
\hline Links with the industry & 3.68 & 3.73 & 0.4588 \\
\hline Multiculturalism & 3.20 & 3.42 & $\mathbf{0 . 0 0 5 3}$ \\
\hline International links & 4.11 & 4.24 & $\mathbf{0 . 0 4 3 6}$ \\
\hline Employment prospects & 4.36 & 4.50 & $\mathbf{0 . 0 0 4 6}$ \\
\hline Flexible study mode & 3.97 & 4.06 & 0.1748 \\
\hline Image of institution & 4.01 & 4.08 & 0.2311 \\
\hline Wilks' lambda value: 4.51 & & \\
\hline & & & \\
\hline
\end{tabular}

The Wilks' lambda value in Table 2 indicated a significant difference $(p=0.0001)$ between males and females in terms of the importance they attached to the different choice factors. The null hypothesis was thus rejected, as there is support for $\mathrm{H}_{1}$.

The follow-up univariate analyses revealed that these differences were significant for 13 of the 23 choice factors, namely: wide choice of subjects/courses; quality of teaching; entry requirements; fees; sport programmes; social life on campus; campus safety and security; on-campus housing; brother/sister went there; friends went there; multiculturalism; international links; and employment prospects.

From Table 2 it can also be observed that the largest differences in mean values (and $p$-values) were evident in: campus safety and security; friends attended the institution; entry requirements; employment prospects; and multiculturalism. All of these factors were significantly more important for female students, except for the item "friends attended the institution", which were more important to male students.

Females also attached a significantly higher importance than males to the wide choice of subjects/courses, quality of teaching, on-campus housing and international links. Males seemed to attach a significantly higher importance to sport programmes, social life on campus and brother/sister attended the institution, than females.

\section{Language group differences}

The top ten choice factors for each language group were determined. To simplify the results for statistical testing and analysis, and due to small language subgroup responses, a decision was made to collapse the responses for all nine African languages into one group, namely "African languages". Due to the small size of the respondents indicating "other home languages" $(2 \%)$, this group was not included in further statistical analyses. Table 3 provides the top ten choice factors (based on mean values) according to the relative importance for each of the three language groups. 
M. Wiese,

C.H. van Heerden,

Y. Jordaan
The role of demographics in students' selection of higher education institutions

Table 3: Top ten choice factors per language group

\begin{tabular}{|c|c|c|c|c|c|c|}
\hline No & African & Mean & Afrikaans & Mean & English & Mean \\
\hline 1 & $\begin{array}{l}\text { Employment } \\
\text { prospects }\end{array}$ & 4.49 & Quality of teaching & 4.63 & Quality of teaching & 4.51 \\
\hline 2 & Quality of teaching & 4.41 & $\begin{array}{l}\text { Employment } \\
\text { prospects }\end{array}$ & 4.44 & Employment prospects & 4.38 \\
\hline 3 & $\begin{array}{l}\text { Campus safety } \\
\text { and security }\end{array}$ & 4.34 & $\begin{array}{l}\text { Campus safety and } \\
\text { security }\end{array}$ & 4.39 & Academic facilities & 4.35 \\
\hline 4 & International links & 4.20 & Language policy & 4.32 & $\begin{array}{l}\text { Campus safety and } \\
\text { security }\end{array}$ & 4.30 \\
\hline 5 & Academic facilities & 4.16 & International links & 4.24 & Academic reputation & \\
\hline 6 & $\begin{array}{l}\text { Flexible study } \\
\text { mode }\end{array}$ & 4.10 & Academic facilities & 4.21 & International links & 4.06 \\
\hline 7 & $\begin{array}{l}\text { Wide choice of } \\
\text { subjects/courses }\end{array}$ & 4.06 & $\begin{array}{l}\text { Image of the } \\
\text { institution }\end{array}$ & 4.18 & Flexible study mode & 3.97 \\
\hline 8 & $\begin{array}{l}\text { Image of the } \\
\text { institution }\end{array}$ & 3.99 & Flexible study mode & 3.98 & \begin{tabular}{|l|} 
Wide choice of \\
subjects/courses
\end{tabular} & 3.92 \\
\hline 9 & Language policy & 3.93 & $\begin{array}{l}\text { Wide choice of } \\
\text { subjects/courses }\end{array}$ & 3.94 & Location & 3.83 \\
\hline 10 & $\begin{array}{l}\text { Links with the } \\
\text { industry }\end{array}$ & 3.85 & $\begin{array}{l}\text { Academic } \\
\text { reputation }\end{array}$ & 3.93 & Links with the industry & 3.80 \\
\hline
\end{tabular}

From Table 3 it is clear that employment prospects and quality of teaching were the two most important factors for all three groups. A notable difference in the ranking order was evident in the importance that Afrikaans students attached to language policy (fourth), while this factor was only ninth on the African language group's ranking, and was not under the top ten for English-speaking students. The image of an institution was more important to Afrikaans- (seventh) and African language-speaking students (eighth) than to the English-speaking students (not included in their top ten). While academic reputation was relatively important to English-speaking students (fifth), it was only tenth on the Afrikaans-speaking students' ranking list and not on the African language-speaking students' top ten list. Location was a choice factor only for the English-speaking group (as part of the top ten) and did not appear on the other two groups' lists.

Hypothesis 2 was to determine whether students who had different home languages differed regarding the importance they attached to any of the 23 choice factors when selecting a HEl. Significant results are indicated in bold print in Table 4. The mean values of the three groups and the MANOVA result of the hypothesis test are also shown in Table 4.

Table 4: Mean values and MANOVA results for different language groups

\begin{tabular}{|l|l|l|l|l|}
\hline CHOICE FACTORS & African & Afrikaans & English & Univariate Analyses \\
\hline $\begin{array}{l}\text { Wide choice of } \\
\text { subjects/courses }\end{array}$ & 4.06 & 3.94 & 3.92 & 0.1430 \\
\hline Quality of teaching & $4.41^{\mathrm{a}}$ & $4.63^{\mathrm{a}}$ & $4.51^{\mathrm{b}}$ & $\mathbf{0 . 0 0 0 2}$ \\
\hline Academic facilities & $4.16^{\mathrm{a}}$ & $4.21^{\mathrm{b}}$ & $4.35^{\mathrm{a}}$ & $\mathbf{0 . 0 4 8 8}$ \\
\hline Entry requirements & 3.84 & 3.68 & 3.71 & 0.0787 \\
\hline Fees & 3.72 & 3.68 & 3.68 & 0.8657 \\
\hline Location of institution & $3.55^{\mathrm{ab}}$ & $3.77^{\mathrm{a}}$ & $3.83^{\mathrm{b}}$ & $\mathbf{0 . 0 0 5 0}$ \\
\hline Sport programmes & $2.45^{\mathrm{ab}}$ & $2.97^{\mathrm{a}}$ & $2.78^{\mathrm{b}}$ & $\mathbf{0 . 0 0 0 0}$ \\
\hline Social life on campus & $2.69^{\mathrm{a}}$ & $3.74^{\mathrm{a}}$ & $3.17^{\mathrm{a}}$ & $\mathbf{0 . 0 0 0 0}$ \\
\hline Attractiveness of campus & $3.33^{\mathrm{b}}$ & $3.77^{\mathrm{ab}}$ & $3.39^{\mathrm{a}}$ & $\mathbf{0 . 0 0 0 0}$ \\
\hline
\end{tabular}


M. Wiese,

C.H. van Heerden, Y. Jordaan
The role of demographics in students' selection of higher education institutions

\begin{tabular}{|l|l|l|l|l|}
\hline Campus safety and security & 4.34 & 4.39 & 4.30 & 0.4388 \\
\hline On-campus housing & $3.07^{\mathrm{a}}$ & $3.66^{\mathrm{a}}$ & $2.40^{\mathrm{a}}$ & $\mathbf{0 . 0 0 0 0}$ \\
\hline $\begin{array}{l}\text { Parents attended the } \\
\text { institution }\end{array}$ & $1.85^{\mathrm{b}}$ & $1.94^{\mathrm{a}}$ & $1.52^{\mathrm{ab}}$ & $\mathbf{0 . 0 0 0 0}$ \\
\hline $\begin{array}{l}\text { Siblings attended the } \\
\text { institution }\end{array}$ & $1.92^{\mathrm{b}}$ & $2.03^{\mathrm{a}}$ & $1.66^{\mathrm{ab}}$ & $\mathbf{0 . 0 0 0 8}$ \\
\hline $\begin{array}{l}\text { Friends attended the } \\
\text { institution }\end{array}$ & $2.12^{\mathrm{b}}$ & $2.65^{\mathrm{ab}}$ & $2.15^{\mathrm{a}}$ & $\mathbf{0 . 0 0 0 0}$ \\
\hline Academic reputation & $4.02^{\mathrm{b}}$ & $3.93^{\mathrm{a}}$ & $4.15^{\mathrm{a}}$ & $\mathbf{0 . 0 1 9 2}$ \\
\hline Financial assistance & $3.82^{\mathrm{b}}$ & $3.82^{\mathrm{a}}$ & $3.39^{\mathrm{ab}}$ & $\mathbf{0 . 0 0 0 0}$ \\
\hline Language policy & $3.93^{\mathrm{a}}$ & $4.32^{\mathrm{ab}}$ & $3.77^{\mathrm{b}}$ & $\mathbf{0 . 0 0 0 0}$ \\
\hline Links with the industry & $3.85^{\mathrm{a}}$ & $3.57^{\mathrm{ab}}$ & $3.80^{\mathrm{b}}$ & $\mathbf{0 . 0 0 0 4}$ \\
\hline Multiculturalism & $3.66^{\mathrm{a}}$ & $3.04^{\mathrm{a}}$ & $3.38^{\mathrm{a}}$ & $\mathbf{0 . 0 0 0 0}$ \\
\hline International links & 4.20 & 4.24 & 4.06 & 0.0641 \\
\hline Employment prospects & 4.49 & 4.44 & 4.38 & 0.2871 \\
\hline Flexible study mode & 4.10 & 3.98 & 3.97 & 0.1715 \\
\hline Image of institution & $3.99^{\mathrm{a}}$ & $4.18^{\mathrm{ab}}$ & $3.91^{\mathrm{a}}$ & $\mathbf{0 . 0 0 1 8}$ \\
\hline $\begin{array}{l}\text { Wilks' lambda } \mathrm{F} \text { value: } 12.44 \\
\text { p-value: } 0.000\end{array}$ \\
\hline
\end{tabular}

Note: The results of the Scheffé post hoc tests are indicated with ${ }^{a}$ and/or ${ }^{b}$. All mean values containing the same letters (for example, ${ }^{a}$ ) indicate that the groups differ significantly from one another. All mean values containing different letters (for example, an ${ }^{a}$ or ${ }^{b}$ ) indicate that these groups do not differ significantly from one another.

Table 4 showed a significant Wilks' lambda value $(p=0.000)$ between the different language groups in terms of the importance they attached to the different choice factors, indicating support for $\mathrm{H}_{2}$. The follow-up univariate analyses indicated that these differences were significant for 17 of the 23 choice factors: quality of teaching, academic facilities, location of the institution, sport programmes, academic reputation, social life on campus, attractiveness of campus, on-campus housing, parents attended the institution, siblings attended the institution, friends attended the institution, academic reputation, financial assistance, language policy, links with the industry, multiculturalism, and the image of the institution.

The Scheffé post hoc tests revealed several interesting differences. A significant difference is apparent between Afrikaans- and African language-speaking students in terms of the importance they attach to quality of teaching. Afrikaans-speaking students attached a higher importance (mean: 4.63) to quality of teaching than African language-speaking students (mean: 4.41). Afrikaans-speaking students also attached a higher importance to the attractiveness of a campus, the image of an institution and the fact that their friends attended the institution, as opposed to English- and African language-speaking students. Afrikaans-speaking students also differed from the other two groups on the importance of links with the industry and an institution's language policy (Afrikaans-speaking students have the lowest mean value).

English-speaking students attached a higher importance to academic facilities than African language- or Afrikaans-speaking students. However, English-speaking respondents attached a lower importance to the statement that their parents and siblings attended an institution, as well as the importance of financial assistance, as opposed to both the African language- and Afrikaans-speaking respondents. An institution's academic reputation was more important to English- than Afrikaans-speaking students. English- and Afrikaans-speaking students differed from African language-speaking students, as they attached a higher importance to the location of an institution and sport programmes.

Multiculturalism and links with the industry were more important to African language-speaking students than the other language groups. All three groups differed from one another regarding social life on campus and 
M. Wiese,

C.H. van Heerden,

Y. Jordaan

The role of demographics in students' selection of higher education

institutions

on-campus housing. African language-speaking students attached the lowest importance (mean: 2.69) to social life, while Afrikaans-speaking students attached the highest importance (mean: 3.74). English-speaking students indicated the lowest importance (mean: 2.40) and the Afrikaans-speaking students the highest importance (mean: 3.66) to on-campus housing.

\section{IMPLICATIONS FOR HIGHER EDUCATION INSTITUTIONS}

The general findings and group differences uncovered in the study can aid HEls in adjusting their recruitment and communication strategies to prospective students. The implications of some of the findings are briefly discussed.

Irrespective of gender or language, the most important choice factor for respondents was the quality of teaching at HEls. Quality of teaching relates to the core service that higher education institutions sell, namely the educational training that the student receives. The most basic level is the core benefit that is being sought, namely that students are not buying degrees, but that they are buying the benefits that a degree can provide in terms of employment, status and lifestyle. The quality of teaching thus refers to the quality of the training process (such as the curriculum, education technologies and methods, and staff qualifications). A solution to the need for quality teaching expressed by respondents will be for HEls to maintain or better their own quality standards, and even align them with globally acceptable quality assurance standards. HEls also need to align the demands of the market place (employers) with the development of current curricula. As a minimum, HEls need to at least communicate the quality standards clearly to the prospective student market.

The findings showed that males and females differ according to the selection of certain choice factors which suggest that HEls can consider recruitment strategies for each gender group. An example of a focused recruitment strategy for male students would be when HEls aim their efforts on the availability of sport programmes within the institution, opportunities for having a social life on campus, and following the tradition of attending an institution that their siblings and/or friends attended or are attending. In addition to the core product (training) that a HEI offers, many also offer value-added services to differentiate themselves from the competition. The male respondents in this study indicated that they value these value-added services such as sport programmes and social activities. Marketing activities aimed at the male segment will thus have to have a strong focus on the value added that the $\mathrm{HEI}$ can offer in addition to quality education.

Institutions that want to target females in general, or attract more females for certain programmes, should focus on the choice factors that distinguished them from males. They can therefore focus on, for example, the existence of a safe and secure campus environment. This is in line with findings from another South African study that also indicated that female students view security as a more important choice factor than their male counterparts (De Jager \& Du Plooy, 2006). Given the high crime rate in South Africa, it is important that institutions ensure a safe and secure learning environment. Technologically advanced security methods can be implemented on campus and in classrooms. Electronic card systems can be used to monitor entrance onto campus and even into classrooms. Institutions can link safety and security to their image and promote themselves as a safe learning environment, especially when attracting female students.

Significant differences between the language groups were found for 17 of the 23 choice factors, signalling that different language groups make decisions based on different choice factors. African language-speaking students have, amongst other, indicated that the multiculturalism of the institution is a very important choice factor for them. One can speculate whether this result supports comments by Higher Education of South Africa (HESA) that some institutions still have alienating institutional cultures (MacGregor, 2009). The findings may therefore suggest that HEls could focus on creating a sense of closeness, acceptance and inclusion to enhance the recruitment of African language-speaking students.

When trying to focus the institution's marketing strategy on English-speaking students, HEls should understand the importance of location of the institution combined with academic reputation and facilities. A 
M. Wiese, C.H. van Heerden, Y. Jordaan
The role of demographics in students' selection of higher education institutions

previous South African study reported that the most important influence upon choice of institution is its reputation, followed by geographical location (De Jager \& Du Plooy, 2006). It has also been noted that one of the reasons why location is important to students is that academic facilities (such as the library) are available at the location (Cosser \& Du Toit, 2002). The academic reputation of an institution has a huge influence on the attitudes of potential students and the image that will impact on a student's willingness to apply to that institution for enrolment. It has been said that an institution's actual quality is often less important than its reputation for quality, because it is their perceived excellence which guides the decisions of prospective students (De Jager \& Du Plooy, 2006). HEls can build their academic reputation with marketing activities such as open days and school visits as well as communicating the availability of bursaries, the institution's national and international standing, and so forth. International partnerships in training and research can enhance an institution's national academic standing, making it a preferred service provider.

One of the choice factor considerations for Afrikaans-speaking students is the language policy of the institution. The Language policy for higher education document identifies that language has been and continues to be a barrier to access and success in higher education, both in the sense that African and other languages (such as Afrikaans) have not been developed as academic/scientific languages (Ministry of Education, 2002). Although multilinguism is acknowledged (without going into the language policy debate), it may be more important for government to launch an intensive, nation-wide campaign to make all South Africans proficient in English (in addition to whatever other language they speak). First, because there is a huge cost to multilinguism; second, since English as a global language is immensely useful in giving citizens access to international literature and global research; and third, because English seems to maintain its status irrespective of the context in which it appears (Foley, 2004; Van der Walt \& Brink, 2005). The challenge for HEls may lie in balancing and managing multilinguism versus the demands of academic output, especially when there is no extra funding or support available from government for the multilinguism agenda. On the one hand, multilinguism (or even bilinguism) has marketing value in creating a niche market, but on the other hand, international academic competitiveness requires other institutional efforts (Van der Walt \& Brink, 2005). Some researchers believe that if non-English home language speakers (such as the Afrikaans market) understand that English plays an empowering role, people will willingly sacrifice their home languages in the interests of economic advancement and international competitiveness (Chew, 1999).

From the findings it is clear that HEls should understand their own offerings and how these are perceived in the marketplace, because it could have important marketing and management implications.

\section{LIMITATIONS AND FUTURE RESEARCH}

The study has several limitations. First, due to the nature of the non-probability sampling method, respondents included in the research are not representative of the broad South African student population. Second, respondents have already selected their institution (first-year students) opposed to Grade 11 and 12 learners currently in the process of higher education selection. It is suggested that future studies attempt to draw a representative sample among Grade 11 and 12 learners. Third, the study did not identify students who were not accepted at their institution of choice and how this may have affected their choice criteria. Lastly, it is important to recognise that the role that economics and socio-cultural background play in restricting choice in the South African context was not included in the study. Despite these limitations, the findings from this research should provide useful guidance to HEls on the importance of choice factors in the institution selection process.

Future studies could consider investigating members of different cultures in terms of how their perceptions of higher education institution selection differ and the way in which they perceive the reality of such choices. Pertaining to the language policy issue that seems to be very important to Afrikaans-speaking students, future studies may want to examine the challenges of HEls to provide in the linguistic needs of the larger student population, while maintaining quality in education and creating an environment where multilinguism can flourish. It may be worthwhile to understand how HEls maintain language policies and their reasons for 
M. Wiese, C.H. van Heerden, Y. Jordaan
The role of demographics in students' selection of higher education institutions

having a policy. Future research could investigate the selection process of students from other study fields to determine if there are similarities with the main findings of this study, as well as determining the similarities or differences between South African students and students from other countries.

\section{CONCLUSION}

The findings provide HEls with an indication of the importance of choice factors considered by students in selecting a HEI. This will enable HEls to use their limited funds more efficiently to attract the right calibre student (recruitment policies), to create a unique position, to segment the student market more appropriately and to gain a competitive advantage. Information obtained from this research also contributes to the available body of knowledge on this topic and could be used by other researchers as a basis for future research. In conclusion, the findings of this study highlight the important role that marketing plays in prospective students' selection of the $\mathrm{HEI}$, mainly because preferences for attending a specific institution are not formed only in a social environment, but also in a marketing environment.

\section{REFERENCES}

Akoojee, S. \& Nkomo, M. 2007. Access and quality in South African higher education: the twin challenges of transformation, South African Journal of Higher Education, 12(3): 385-399.

Arnould, E., Price, L. \& Zinkhan, G. 2004. Consumers, Second edition, McGraw-Hill: New York.

Arpan, L.M., Raney, A.A. \& Zivnuska, S. 2003. A cognitive approach to understanding university image, Corporate Communications, 8(2): 97-113.

Bajsh, A. \& Hoyt, J.E. 2001. The effect of academic scholarship on college attendance, College and University, 76(4): 3-8.

Bechan, N. \& Visser, R. 2005. The influence of language on culture on a South African corporate, Communicare, 24(2): 66-81.

Berman, B. \& Evans, J.R. 2001. Retail management: A strategic approach, 8th edition, Prentice Hall: New Jersey.

Bers, T.H. \& Galowich, P.M. 2002. Using survey and focus group research to learn about parents' role in the community college-choice process, Community College Review, 29(4): 68-82.

Bonnema, J. \& Van Der Waldt, D. 2008. Information preferences of a student market in higher education, International Journal of Education Management, 22(4): 314-27.

Bradshaw, G.S., Espinoza, S. \& Hausman, S. 2001. The college decision-making of high achieving students, College and University, 77(2): 15-22.

Brand, G. 2003. Imagining a multilingual academy: rethinking language in higher education, South African Journal of Higher Education, 17(3): 26-35.

Chapman, D.W. 1981. A model of student college-choice, Journal of Higher Education, 52(5): 490-505.

Chew, P.G. 1999. Linguistic imperialism, globalism and the English language, The AlLA Review, 13: 37-47.

College Board. 2005. Recruitment and Admission: ASQ and ASQ PLUS. [Online]. Available at: http://www.collegeboard.com/highered/ra/asq.htmlp (Accessed May 2005).

Cosser, M. \& Du Toit, J. 2002. From school to higher education: Factors affecting the choice of grade 12 learners, HSRC Publishers: Cape Town.

Davis, K. 1998. State universities to cheer about affording college, Kiplinger's Personal Finance Magazine, September 1998.

De Jager, J.W. \& Du Plooy, A.T. 2006. Student's expectations of service quality in tertiary education: A comparison between prospective and current students, Acta Commercii, 6: 10-19.

De Vries, A. 2007. Universiteite van die hele wye wêreld, Rapport, November 18: 2.

Desjardins, S.L., Dunbar, H. \& Hendel, D.D. 1999. Modeling the college application decision process in a Land-Grand University, Economics of Education Review, 18(1): 117-132.

Divala, J. \& Waghid, Y. 2007. An analysis of equal educational opportunities: comparative perspectives in education law, South African Journal of Higher Education, 21(4): 799-808. 
M. Wiese,

C.H. van Heerden,

Y. Jordaan
The role of demographics in students' selection of higher education institutions

Drew, T. \& Michael C. 2006. How do students choose a university? An analysis of application to universities in Ontario, Canada, Research in Higher Education, 47(7): 781-800.

Du Plessis, P.J. \& Rousseau, G.G. 2003. Buyer behaviour: A multi-cultural approach, Third edition, Oxford: Cape Town.

Espinoza, S., Bradshaw, G. \& Hausman C. 2002. The importance of college factors from the perspective of high school counselors, College and University, 77(4): 19-24.

Foley, A. 2004. Language policy for higher education in South Africa: implications and complications, South African Journal of Higher Education, 18(1): 57-71.

Freeman, K. 1999. Will higher education make a difference? Black African Americans' economic expectations and college-choice, College and University, Fall(2): 7-13.

Galotti, K.M. \& Mark, M.C. 1994. How do high school students structure an important life-decision? A shortterm longitudinal study of the college decision-making process, Research in Higher Education, 35(5): 589-608.

Geraghty, M. 1997. Finances are becoming more crucial in students' college-choice, The Chronicle of Higher Education, 7(43): 19-41.

Gray, M. \& Daugherty, M. 2004. Factors that influence students to enroll in technology education programmes, Journal of Technology Education, 15(2): 23-31.

Hannukainen, K. 2008. Why do Chinese students choose to study in the Helsinki Region? [Online]. Available at: http://www.helsinki.fi/news/archive/8-2008/19-12-12-42. (Accessed January 2009).

Hawkins, D.I., Best, R.J. \& Coney, K.A. 2004. Consumer behaviour: building marketing strategy, Ninth edition, McGraw-Hill: New York.

Hay,H.R. 2008. If walls could speak: Reflections from visiting a South African higher education classroom, South African Journal of Higher Education, 22(5): 935-947.

Higher Education Research Institute. 2004. Cooperative Institutional Research Progamme - CIRP: The Freshman Survey, Higher Education Research Institute, UCLA. [Online] Available at http://www.gseis.ucla.edu/heri/. (Accessed: June 2004).

Higher Education South Africa. 2008. Higher education study in South Africa. Mail and Guardian, 15 May: 5.

Hoyer, W.D. \& Macinnis, D.J. 2001. Consumer behaviour, Second edition, Houghton Mifflin: Boston.

Hoyt, J.F. \& Brown, A.B. 2003. Identifying college choice factors to successfully market your institution, College and University, 78(4): 3-5.

Jansen, J.D. 2003. On the state of South African universities, South African Journal of Higher Education, 17(3): 9-12.

Kealy, M.J. \& Rockel, K.L. 1987. Student perceptions of college quality: The influence of college recruitment policies, The Journal of Higher Education, 58(6): 683-703.

Litten, H. 1982. Different stroke in the application pool: Some refinements in a model of student college choice, The Journal of Higher Education, 53(4): 383-402.

MacGregor, K. 2009. South Africa: Debate moves on from access to success. University World News. http://www.universityworldnews.com/article.php?story=20090313111607177 (accessed May 29, 2009).

Mansfield, P.M. 2005. Gender differences in students' and parents' evaluative criteria when selecting a college, Journal of Marketing for Higher Education, 15(2): 47-80.

Martin, C.D. 1994. How do rural students choose a campus: A case study of the University of South Australia, Rural Society, 5(2): 28-36.

Meier, C. 2007. Enhancing intercultural understanding using e-learning strategies, South African Journal of Education, 27: 655-671.

Menon, M.E., Saiti, A. \& Socratous, M. 2007. Rationality, information search and choice in higher education: evidence form Greece, Higher Education, 54: 705-721.

Mills, M. 2004. Do and should financial aid packages affect student's college-choices?, Journal of College Admission, Spring(183): 28-29.

Ministry Of Education. 2002. National Plan for Higher Education in South Africa. Department of Education: Republic of South Africa.

Price, I.F., Matzdorf, F., Smith, L. \& Aghai, H. 2003. The impact of facilities on student choice of university, Facilities, 21(10): 212-230. 
M. Wiese,

C.H. van Heerden, Y. Jordaan
The role of demographics in students' selection of higher education institutions

Punnarach, S. 2004. The image of private universities from high school students and occupational students viewpoint, DSc thesis, Bangkok: Kasem Bundit University.

Rindfleish, J.M. 2003. Segment profiling: reducing strategic risk in higher education managements, Journal of Higher Education Policy and Management, 25(2): 147-159.

Sevier, R.A. 1993. Recruiting Black African American undergraduates. A national survey of the factors that affect institutional choice, Colleges and University, 68(1): 48-52.

Sheth, J.N., Mittal, B. \& Newmand, B.I. 1999. Consumer behaviour and beyond, Dryden Press: Orlando.

Shin, J. \& Milton, S. 2006. Rethinking tuition effects on enrollments in public four-year colleges, The Review of Higher Education, 29(6): 213-237.

Smit, D.G. \& Schonefield, N.B. 2000. The benefits of diversity, About Campus, Nov/Dec: 16-23.

Van der Walt, C. \& Brink, C. 2005. Multilingual universities: a national and international overview, South African Journal of Higher Education, 19(4): 822-861.

Van Dimitrios, P. 1980. A marketing study for higher education using Southeast Missouri State University and its service area. PhD dissertation., Southern Illinois University at Carbondale.

Van Louw, T. \& Beets, P.A.D. 2008. The transformation of higher education: Context of the establishment of the Centre for Leadership and Management in Education at Stellenbosch University, South African Journal of Higher Education, 22(3): 473-483.

Van Niekerk, M.P. 2004. The national plan for higher education in South Africa and Black African indigenous knowledge systems: A case of conflicting value system, South African Journal of Higher Education, 18(3): 115-126.

Wangenge-Ouma, G. \& Cloete N. 2008. Financing higher education in South Africa: Public funding, nongovernment revenue and tuition fees, South African Journal of Higher Education 22(4): 906-919.

Whyte, A. 2001. Positioning Australian universities for the twenty first century, Open Learning, 16(1): 27-33. 